\title{
Fibers for Ceramic Matrix Composites
}

Bernd Clauß

\section{1}

\section{Introduction}

New materials and processing routes provide opportunities for the production of advanced high performance structures for different applications. Ceramic matrix composites (CMCs) are one of these promising materials. By combining different ceramic matrix materials with special suitable fibers, new properties can be created and tailored for interesting technical fields.

This chapter gives an overview on fiber types, which can be used as fibrous components in CMCs [1-5]. The production of these fibers, as well as their structure and properties, will be discussed.

\section{2}

\section{Fibers as Reinforcement in Ceramics}

In CMCs, only fiber components are used that withstand the relatively high temperatures required for the production of ceramics, without significant damage. Other requirements to be met are long-term high-temperature stability, creep resistance, and oxidation stability. The importance of each of these demands depends on the type of application.

Organic, polymeric fiber materials cannot be used in CMCs because of their degradation at temperatures below $500^{\circ} \mathrm{C}$. Also conventional glass fibers, with melting or softening points below $700^{\circ} \mathrm{C}$, cannot be used for this purpose.

Possible candidates for the reinforcement of ceramic materials are polycrystalline or amorphous inorganic fibers or carbon fibers. The term "ceramic fibers" summarizes all non-metallic inorganic fibers (oxide or non-oxide), with the exception of fibers manufactured via solidification of glass melts.

The distinction between ceramic fibers and glass fibers has become more difficult during the last few years, because ceramics produced via new precursor or sol-gel routes can also be amorphous (i.e. "glassy") in structure and the production process can also contain a melt processing step. This means that ceramic fibers can be 
Fibers

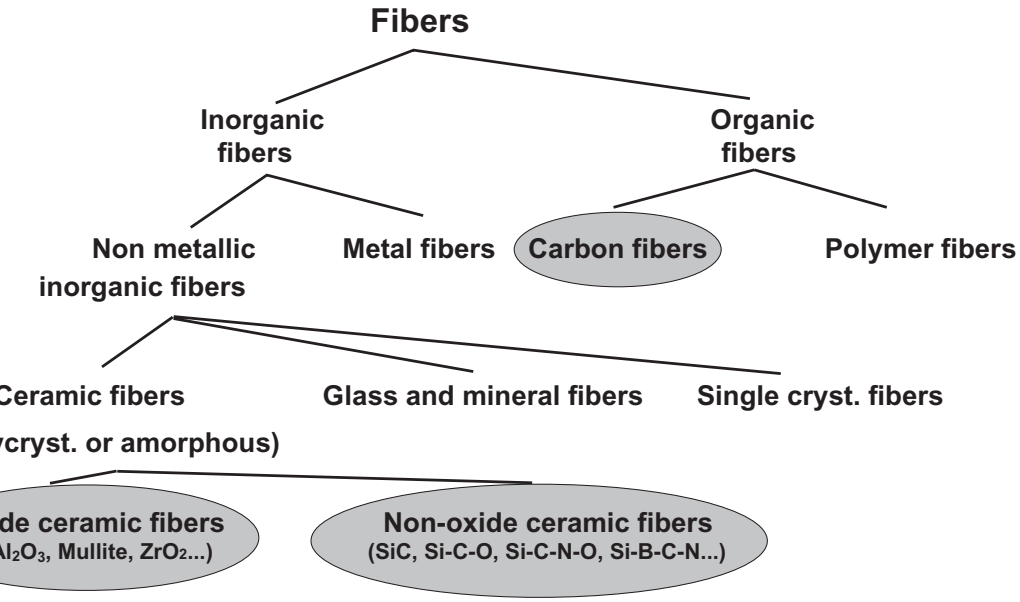

Figure 1.1 Classification of different fiber types.

either polycrystalline, partially crystalline, or amorphous. However, the expression "glass fibers" should only be applied to fibers that are produced via solidification of typical glass melts based on silicate systems. If these melts are produced by using minerals such as basalt, then the fibers should be called "mineral fibers."

Carbon fibers can also be used under certain conditions in CMCs. Although these fibers degrade in an oxidizing atmosphere above $450^{\circ} \mathrm{C}$, they are stable under non-oxidizing conditions up to temperatures of $2800^{\circ} \mathrm{C}$. Carbon fibers have a very good cost-performance ratio, if an environmental protection of the composite allows the use of this fiber type. Therefore, environmental barrier coatings (EBC) is an important field of research in CMCs.

Figure 1.1 shows a general classification of fibers, containing ceramic fibers and carbon fibers.

\section{3}

\section{Structure and Properties of Fibers}

Fibers used in high-performance composites possess superior mechanical properties (and in CMCs also superior thermal properties) compared to "normal" polymeric fibers. This chapter will discuss how this can be achieved with fibers made from different materials, including polymers, glass, ceramics, and carbon.

\subsection{1}

\section{Fiber Structure}

As shown in Figure 1.2, the structure of fibers can be considered from different viewpoints, depending on the "magnification" at which the structure is presented. The example shown is a polymeric fiber. 


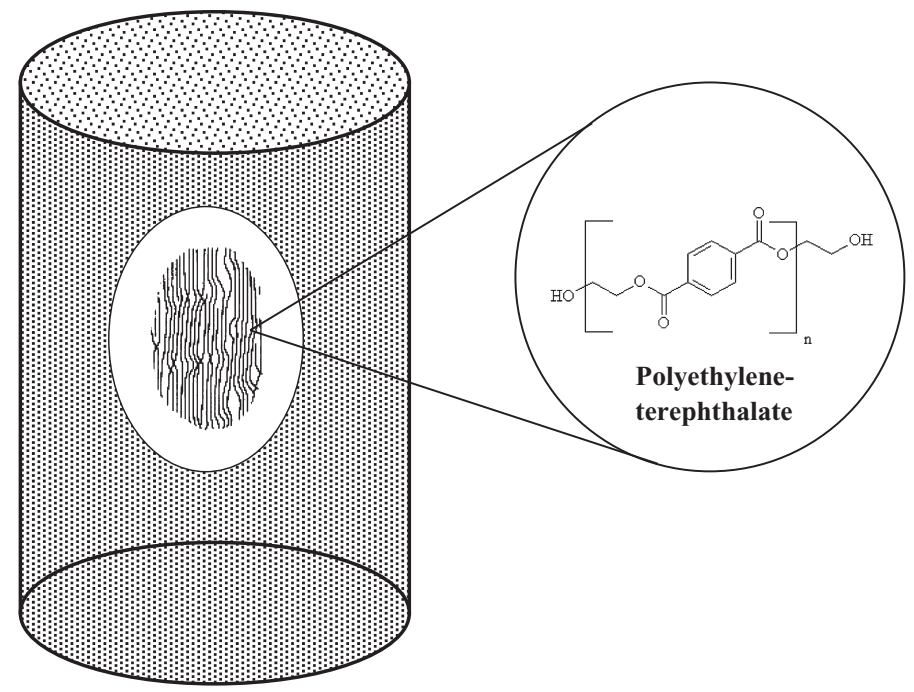

Figure 1.2 Fiber structure (example PET fiber).

At the molecular level, the displayed fiber is composed of poly(ethyleneterephthalate) (PET) chain molecules. This "chemical structure" determines the thermal and chemical stability and the theoretical strength of the fiber.

Most fibers also possess supramolecular structures, which are determined by molecular orientation and crystalline and/or amorphous regions (e.g. a two-phase crystalline and amorphous structure is indicated in Figure 1.2). These structures are formed during processing and can be significantly influenced by the processing conditions. This "physical structure" has important influence on the thermomechanical properties of fibers.

Finally, the fiber morphology influences the properties at the macroscopic level. Important criteria are cross-section, uniformity of the diameter along the fiber, porosity, and structural flaws, as well as surface properties such as roughness and surface energy (which is determined by the chemical structure of the surface). Adhesion to the matrix material and wetting behavior during infiltration steps are strongly influenced by these properties.

\subsection{2}

\section{Structure Formation}

The structure formation in fibers depends not only on the fiber material itself but also on the processing conditions. Process parameters are controlled in such a way that specific supramolecular and macroscopic structures can be obtained.

Important manufacturing processes are meltspinning, dryspinning, and wetspinning, together with modified spinning processes related to these: 
- In the melt spinning process, fibers are formed via melts, which are forced through nozzles at high pressure and then solidified by cooling.

- In the dry spinning process, polymer solutions are used, which are also spun through nozzles. In this case, the fiber formation occurs by evaporation of the solvent from the spun solution.

- In the wet spinning process, polymer solutions are also used, but fiber forms by precipitation of the polymer in a liquid precipitation bath.

Important process parameters that influence the structure formation of the fibers are spinning speed, draw ratio, temperature, and other ambient conditions.

If specialty fibers are desired, the spinning process is often followed by after treatments, which will determine the final structure of the fibers.

Such after treatments include cross-linking of melt spun ceramic precursors before pyrolysis, annealing, and sintering of oxide based green fibers in order to achieve ceramic fibers and special surface treatments of carbon fibers.

If ceramic or carbon fibers are to be used in CMCs, the fibers have to be coated in many cases (e.g. with pyrocarbon or boron nitride), which act as interfaces between fiber and matrix.

\section{3 .3}

\section{Structure Parameters and Fiber Properties}

The physical properties of fibers are determined essentially by three structure parameters: bond type, crystallinity, and molecular orientation [6].

The energy content of different types of chemical bonds is illustrated in Table 1.1. Covalent and ionic bonds, which can be oriented one-, two-, or threedimensionally within fibers, have the highest energy content and so determine the mechanical strength and modulus of the fibers. Other bond types are of minor importance in high-performance fibers.

Different fiber types are shown in Table 1.2, which are distinguished by the structural parameters listed. It is obvious that the fibers possess different architectures and the final properties of the fibers (e.g. modulus and strength) are determined by a combination of these structural parameters.

If the bond type and the spatial orientation of the bonds were the main criterion for good mechanical properties, then ceramic fibers and glass fibers with threedimensional, covalent, or ionic bonds would have far superior properties compared to other fiber types. But since these fibers are isotropic without molecular orientation, they possess lower strength than carbon fibers. This is because carbon fibers have a structure with two-dimensional covalent bonds, showing pronounced crystallinity and high orientation. Based on this advantageous combination of structural parameters, carbon fibers currently display the highest values for strength and modulus. Depending on the processing conditions, carbon fibers can achieve either moduli as high as $600 \mathrm{GPa}$, or extremely high strength values (above $7000 \mathrm{GPa})$. 
Table 1.1 Chemical bond types and bond energies with examples of materials [6].

\begin{tabular}{llll}
\hline Bond type & Energy $\left(\mathbf{k} \mathbf{~ m o l}^{-1}\right)$ & Examples & \\
\hline Ionic & $800-15000$ & $\mathrm{NaCl}$ & $3 \mathrm{D}$ \\
& & $\mathrm{ZrO}_{2}$ & $3 \mathrm{D}$ \\
& & $\mathrm{Al}_{2} \mathrm{O}_{3}$ & $3 \mathrm{D}$ \\
Covalent & $200-600$ (single bonds) & Aramide & 1D \\
& & Graphite (in plane) & 2D \\
& & Glass, SiC & $3 \mathrm{D}$ \\
Metallic & $100-800$ & Metals & \\
Hydrogen bonds & $20-50$ & Aramide & \\
& & Aliphat. polyamide \\
Dipole-dipole & & Cellulose \\
van der Waals & ca. 2 & Polyester \\
& ca. 1 & Polyolefines \\
& & Graphite (between planes) \\
\hline
\end{tabular}

Table 1.2 Fiber structures and properties [6].

\begin{tabular}{|c|c|c|c|c|c|}
\hline Fiber type & Polyester polyamide & $\begin{array}{l}\text { Aramide fibers } \\
\text { from LC phase }\end{array}$ & Carbon & $\begin{array}{l}\text { Ceramic } \\
\text { (crystalline) }\end{array}$ & $\begin{array}{l}\text { Ceramic } \\
\text { (amorphous) } \\
\text { glass }\end{array}$ \\
\hline \multicolumn{6}{|l|}{ Structure } \\
\hline & $\begin{array}{l}\text { 1D linear } \\
2 \text { phases }\end{array}$ & $\begin{array}{l}\text { 1D linear } \\
1 \text { phase }\end{array}$ & 2D layered & $3 \mathrm{D}$ isotropic & 3D isotropic \\
\hline Bond type & $\begin{array}{l}\text { 1D covalent, hydrogen } \\
\text { bonds (PA), dipole- } \\
\text { dipole (PES), van der } \\
\text { Waals }\end{array}$ & $\begin{array}{l}\text { 1D covalent, } \\
\text { hydrogen } \\
\text { bonds, van } \\
\text { der Waals }\end{array}$ & $\begin{array}{l}\text { 2D covalent, } \\
\text { van der } \\
\text { Waals }\end{array}$ & $\begin{array}{l}\text { 3D covalent/ } \\
\text { ionic }\end{array}$ & $\begin{array}{l}\text { 3D covalent/ } \\
\text { ionic }\end{array}$ \\
\hline Crystallinity & Medium & Paracyrstalline & Paracrystalline & Polycrystalline & Amorphous \\
\hline Orientation & Medium & Very high & High & None & None \\
\hline
\end{tabular}

Polymeric aramide fibers also show high strength values due to their high molecular orientation in the fiber axis, although only one-dimensional covalent bonds and hydrogen bonds are present.

Figures 1.3 and 1.4 show an overview of mechanical properties of different fiber types. Averages are given because, as mentioned before, properties can differ depending on processing conditions. In reality, no perfect fiber structure can be 


\section{Tensile Strength}

[MPa]

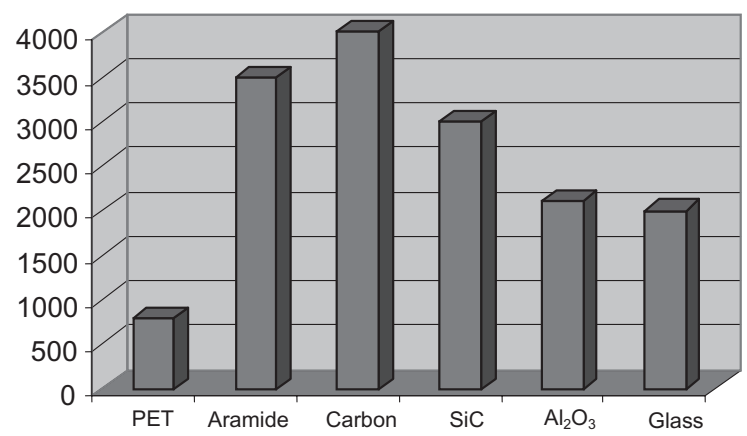

Fiber types

Figure 1.3 Typical tensile strengths (averages) of different fiber types.

\section{Tensile modulus}

[GPa]

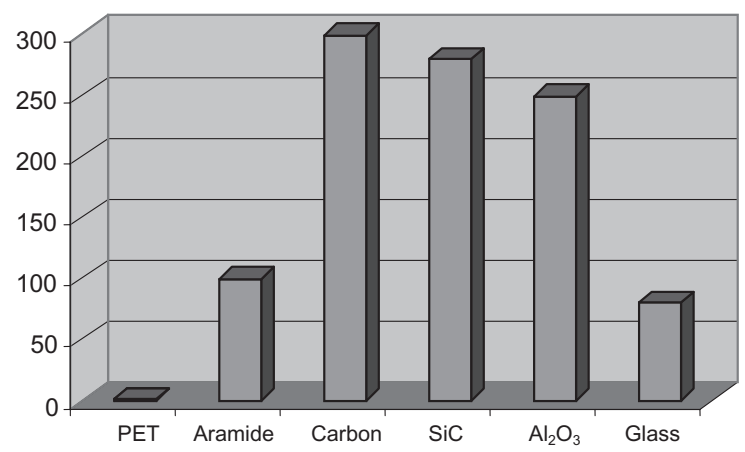

Fiber types

Figure 1.4 Typical tensile moduli (averages) of different fiber types.

obtained during processing, which means that the real properties of fibers are usually far below the theoretical property values calculated for a perfect structure. Therefore, one important goal of a fiber spinning and fiber formation process is to reduce structure imperfections to a minimum by optimized process control. Relatively high prices of high-performance fibers are usually caused by highly sophisticated and complex manufacturing processes rather than by more expensive materials used in the fiber production. 


\section{4}

\section{Inorganic Fibers}

\subsection{1}

\section{Production Processes}

The manufacturing processes for inorganic fibers can be divided in two categories: One process is called "indirect," as the fibers or the non-ceramic precursor fibers are not obtained by a spinning process, but by using other fiber materials. The fiber is soaked with a pre-ceramic precursor material, or the precursor material is deposited on the surface. The inorganic fiber is then formed by pyrolysis of the organic template fiber.

In the second route, called "direct process," inorganic precursors (salt solutions, sols, or precursor melts) are directly spun into so-called "green fibers," in some cases by using organic polymer additives.

Another important distinction of production processes is based on the fiber length. There exist production processes for endless fibers as well as for short fibers, with fiber lengths from millimeters to some centimeters. Short fibers are usually produced by fibrillation of spinning dopes using fast rotating discs or by air-blowing techniques.

In addition, a process is conducted in which fabrics made of cellulosic short fibers are saturated with precursors and then pyrolysed and sintered in order to transform the material into a ceramic fiber fabric [7].

Figure 1.5 shows a schematic depiction of the production of ceramic fibers and Figure 1.6 shows a dry spinning line for the production of endless, oxide based green fibers.

\subsubsection{Indirect Fiber Production}

CVD Process In the CVD process, ceramic fibers are formed via gas phase deposition of ceramic materials on carrier fibers. The carrier fiber usually forms the core of the ceramic fiber. Examples of core materials are carbon fibers and tungsten wires.

Relic Process In the so-called "relic process," absorbent organic fiber materials (mostly cellulose-based) are saturated with salt solutions or sols. Afterwards the organic material is burned off and the salt or sol is converted into a ceramic material at high temperature to obtain ceramic fibers.

\subsubsection{Direct Fiber Production}

Direct fibre production processes can be distinguished by the pre-ceramic precursor components used in the spinning dopes:

Spinning Dopes Based on Molecularly Dispersed Precursors In these processes, soluble salts are used in the spinning dopes, which can be converted into ceramics 
Precursor systems

with inorganic and organic components (mostly without addition of ceramic powders)

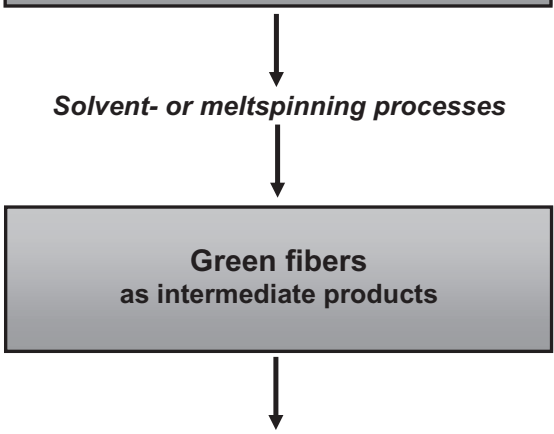

Pyrolysis / Sintering

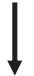

Polycrystalline or amorphous ceramic fibers
Figure 1.5 Production route of ceramic fibers.

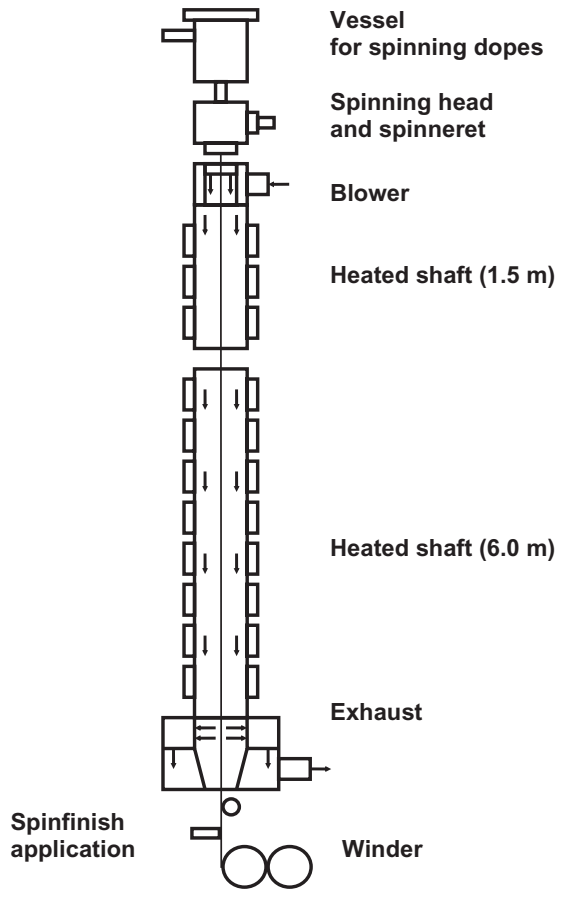

Figure 1.6 Dry spinning facility at ITCF, Denkendorf, for spinning of oxide forming green fibers. 
by a calcination step. Although the salts are dissolved in the form of ions, that is, dispersed at the molecular scale, these processes are often incorrectly summarized under "sol-gel" processes.

In addition to the salt, the spinning dope consists of organic polymers such as poly(ethylenoxide), poly(vinylalcohol), or poly(vinylpyrrolidone), in order to achieve the rheological behavior needed for the spinning process. Solvents are usually water or water/alcohol mixtures. In some cases, nano-scaled ceramic particles are added to the dope to control the structure formation during ceramization.

Spinning Dopes Based on Colloidally Dispersed Precursors This process is similar to the one mentioned above, but here colloidal inorganic components are used as pre-ceramic precursors (i.e. particle sols). In this case, the term "sol-gel process" is appropriate. The organic polymers, which have to be added in order to achieve spinnability, are the same as in the above process, with the same solvents also being used.

Spinning Dopes Containing Coarse Ceramic Particles (Ceramic Powders) Sometimes, coarse ceramic particles are added to salt- or sol-based spinning dopes in order to increase the ceramic yield and to reduce the shrinkage during calcinations and sintering. In this case, the process is called the "slurry process."

Spinning Dopes Based on Inorganic Polymers In these so-called "precursor or precursor-polymer processes," the spinning dope consists of either a solution of an inorganic polymer, which can be spun via a dry spinning process or the precursor-polymers are fusible and can be spun using a melt spinning process. Here no addition of organic polymer is necessary since the solution or the melt already possess the visco-elastic rheological behavior needed to be spun into fibers.

The inorganic polymers usually carry organic functional groups such as methylor propyl-groups, so that during pyrolysis this organic material also has to be burned off. However, these systems have significantly higher ceramic yields compared to the processes described above. The precursors, which are melt spun, have to be cross-linked (either chemically or by high energy radiation) before pyrolysis, otherwise the material would re-melt and lose its fiber shape if heated above the melting point.

\section{4 .2}

\section{Properties of Commercial Products}

\subsubsection{Comparison of Oxide and Non-oxide Ceramic Fibers}

Oxide fibers, currently available commercially, are mostly based on $\mathrm{Al}_{2} \mathrm{O}_{3}$ - or $\mathrm{Al}_{2} \mathrm{O}_{3} / \mathrm{SiO}_{2}$ ceramics. They possess high values for tensile strength and modulus, and due to their oxidic nature are stable against oxidation at high temperatures.

Unfortunately, even the best polycrystalline oxide fibers are prone to creep under load at $1100^{\circ} \mathrm{C}$. Above this temperature the fibers cannot be used in CMCs for 
long-time applications. Also oxide fibers tend to form larger grains when kept at high temperatures over long time periods. The larger grains tend to grow at the expense of smaller grains because of diffusion processes at grain boundaries, which can lead to brittle fibers.

Commercially available non-oxide ceramic fibers are based on $\mathrm{SiC}$ and $\mathrm{Si}-\mathrm{C}-(\mathrm{N})-\mathrm{O}$ materials, which contain undesirable oxygen to a greater or lesser extent and can also contain $\mathrm{Ti}$, $\mathrm{Zr}$, or $\mathrm{Al}$.

Non-oxide fibers also exhibit high values for tensile strength and modulus (even higher than oxide fibers) and due to their structure, which is amorphous in many cases, they possess lower creep rates at high temperatures compared to the polycrystalline oxide fibers. Disadvantages of these fibers are their susceptibility to oxidation, which leads to fiber degradation in an oxidizing atmosphere over time. The lower the oxygen content of the fiber itself, the better its oxidation resistance.

The production process, which requires an inert atmosphere in most cases, is complex. Especially in the fabrication of low oxygen fibers ( $<1 \mathrm{wt} .-\%$ oxygen), such as the Hi-Nicalon types or Sylramic, sophisticated technologies are needed, which lead to high fiber prices.

The limitations of both oxide and non-oxide fiber types have to be known in order to choose the proper material for the intended application.

Current research activities are focused on the development of oxide fibers with enhanced creep properties und reduced grain growth rates, as well as on the development of non-oxide fibers with improved oxidation stability and lower production costs [8-16].

\subsubsection{Oxide Ceramic Filament Fibers}

Table 1.3 gives an overview of commercially available oxide ceramic filament fibers (i.e. endless fibers). The specifications given are taken from product information of the fiber producers [17-20]. The reported prices are for quantities of over $100 \mathrm{~kg}$ of fiber and are usually higher for lower quantities. The "denier" given for the $3 \mathrm{M}$ fibers is a unit of measure for the linear mass density of fibers. It is defined as the mass in grams per 9000 meters. In the International System of Units, the "dtex" is used instead, which is the mass in grams per 10000 meters. Since the fibers have different densities, the denier does not indicate directly the number of filaments. For Nextel 720, "3000 den" corresponds to about 900 filaments; for Nextel 610, "3000 den" corresponds to about 800 filaments; for Nextel 550 and 440, "2000 den" corresponds to about 700 filaments; and for Nextel 312, "1800 den" also corresponds to about 700 filaments (if fiber diameters of $12 \mu \mathrm{m}$ are assumed).

Nevertheless, no responsibility can be taken for the correctness of this information.

Figure 1.7 shows the structure of a $10 \mu \mathrm{m}$ mullite-based oxide fiber developed at ITCF, Denkendorf (Germany), as an example of a new oxidic ceramic fiber [21, 22]. 
Table 1.3 Overview about commercial oxide ceramic filament fibers.

\begin{tabular}{|c|c|c|c|c|c|c|}
\hline $\begin{array}{l}\text { Producer } \\
\text { Fiber }\end{array}$ & $\begin{array}{l}\text { Composition } \\
\text { (Wt.-\%) }\end{array}$ & $\begin{array}{l}\text { Diameter } \\
(\mu \mathrm{m})\end{array}$ & $\begin{array}{l}\text { Density } \\
\left(\mathrm{g} / \mathrm{cm}^{3}\right)\end{array}$ & $\begin{array}{l}\text { Tensile } \\
\text { strength/ } \\
\text { modulus } \\
(\mathrm{MPa} / \mathrm{GPa})\end{array}$ & $\begin{array}{l}\text { Production } \\
\text { technique/ } \\
\text { structure }\end{array}$ & Approx. price \\
\hline $\begin{array}{l}3 \mathrm{M} \\
\text { Nextel } 720\end{array}$ & $\begin{array}{r}\mathrm{Al}_{2} \mathrm{O}_{3}: 85 \\
\mathrm{SiO}_{2}: 15\end{array}$ & $10-12$ & 3.4 & $2100 / 260$ & $\begin{array}{l}\text { Sol-Gel/ } \\
\quad 59 \text { vol. } \% \alpha-\mathrm{Al}_{2} \mathrm{O}_{3} \\
+ \\
\quad 41 \text { vol. } \% \text { Mullite }\end{array}$ & $\begin{array}{l}€ 790 / \mathrm{kg} \\
\quad(1500 \text { den }) \\
€ 600 / \mathrm{kg} \\
\quad(3000 \text { den })\end{array}$ \\
\hline $\begin{array}{l}3 \mathrm{M} \\
\text { Nextel } 610\end{array}$ & $\mathrm{Al}_{2} \mathrm{O}_{3}:>99$ & $10-12$ & 3.9 & $3100 / 380$ & $\begin{array}{l}\text { Sol-Gel/ } \\
\quad \alpha-\mathrm{Al}_{2} \mathrm{O}_{3}\end{array}$ & $\begin{array}{l}€ 790 / \mathrm{kg} \\
(1500 \mathrm{den}) \\
€ 600 / \mathrm{kg} \\
(3000 \mathrm{den}) \\
€ 440 / \mathrm{kg} \\
\quad(10000 \mathrm{den})\end{array}$ \\
\hline $\begin{array}{l}3 \mathrm{M} \\
\text { Nextel } 550\end{array}$ & $\begin{array}{r}\mathrm{Al}_{2} \mathrm{O}_{3}: 73 \\
\mathrm{SiO}_{2}: 27\end{array}$ & $10-12$ & 3.03 & $2000 / 193$ & $\begin{array}{l}\text { Sol-Gel } / \gamma-\mathrm{Al}_{2} \mathrm{O}_{3}+ \\
\mathrm{SiO}_{2} \text { amorph. }\end{array}$ & $\begin{array}{l}€ 590 / \mathrm{kg} \\
\quad(2000 \text { den })\end{array}$ \\
\hline $\begin{array}{l}3 \mathrm{M} \\
\text { Nextel } 440\end{array}$ & $\begin{array}{l}\mathrm{Al}_{2} \mathrm{O}_{3}: 70 \\
\mathrm{SiO}_{2}: 28 \\
\mathrm{~B}_{2} \mathrm{O}_{3}: 2\end{array}$ & $10-12$ & 3.05 & $2000 / 190$ & $\begin{array}{l}\text { Sol-Gel } / \gamma-\mathrm{Al}_{2} \mathrm{O}_{3}+ \\
\quad \text { Mullite }+\mathrm{SiO}_{2} \text { amorph. }\end{array}$ & $\begin{array}{l}€ 500 / \mathrm{kg} \\
\quad(2000 \text { den })\end{array}$ \\
\hline $\begin{array}{l}3 \mathrm{M} \\
\text { Nextel } 312\end{array}$ & $\begin{array}{c}\mathrm{Al}_{2} \mathrm{O}_{3}: 62.5 \\
\mathrm{SiO}_{2}: 24.5 \\
\mathrm{~B}_{2} \mathrm{O}_{3}: 13\end{array}$ & $10-12$ & 2.7 & $1700 / 150$ & $\begin{array}{l}\text { Sol-Gel/Mullite + } \\
\text { amorph. or } 100 \% \\
\text { amorph }\end{array}$ & $\begin{array}{l}€ 260 / \mathrm{kg} \\
\quad(1800 \mathrm{den})\end{array}$ \\
\hline $\begin{array}{l}\text { Sumitomo } \\
\text { Altex }\end{array}$ & $\begin{array}{r}\mathrm{Al}_{2} \mathrm{O}_{3}: 85 \\
\mathrm{SiO}_{2}: 15\end{array}$ & $10 / 15$ & 3.3 & $1800 / 210$ & $\begin{array}{l}\text { Polyaluminoxane/ } \\
\gamma-\mathrm{Al}_{2} \mathrm{O}_{3}\end{array}$ & $€ 640-720 / \mathrm{kg}$ \\
\hline $\begin{array}{l}\text { Nitivy } \\
\text { Nitivy } \\
\text { ALF }\end{array}$ & $\begin{array}{r}\mathrm{Al}_{2} \mathrm{O}_{3}: 72 \\
\mathrm{SiO}_{2}: 28\end{array}$ & 7 & 2.9 & $2000 / 170$ & Sol-Gel $/ \gamma-\mathrm{Al}_{2} \mathrm{O}_{3}$ & $\begin{array}{l}€ 390 / \mathrm{kg} \text { (twisted } \\
\text { yarn, twists: } \\
10-15 \text { ) }\end{array}$ \\
\hline $\begin{array}{l}\text { Mitsui } \\
\text { Almax-B }\end{array}$ & $\begin{array}{r}\mathrm{Al}_{2} \mathrm{O}_{3}: 60-80 \\
\mathrm{SiO}_{2}: 40-20\end{array}$ & $7-10$ & 2.9 & Not available & Unknown $/ \delta-\mathrm{Al}_{2} \mathrm{O}_{3}$ & Price not available \\
\hline
\end{tabular}

\subsubsection{Non-oxide Ceramic Filament Fibers}

Table 1.4 gives an overview of commercially available (some only in smaller quantities) non-oxide filament fibers [23-26]. Prices for the Nicalon fibers were provided by the North American distributor COI Ceramics Inc. Nevertheless, no responsibility can be taken for the correctness of this information.

Figure 1.8 shows an example of an amorphous non-oxide Si-C-N fiber after temperature treatment at $1500^{\circ} \mathrm{C}$ for 12 hours in air. This fiber was produced at ITCF, Denkendorf with a precursor material from the Department of Ceramic Materials Engineering of the University of Bayreuth [27, 28]. Beside the oxidation layer of silicon dioxide at the fiber surface, no further degradation can be observed. 
(a)

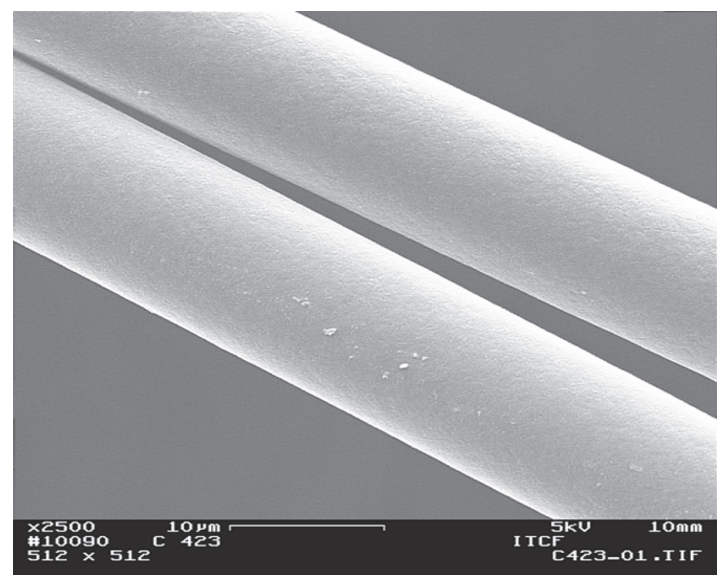

(b)

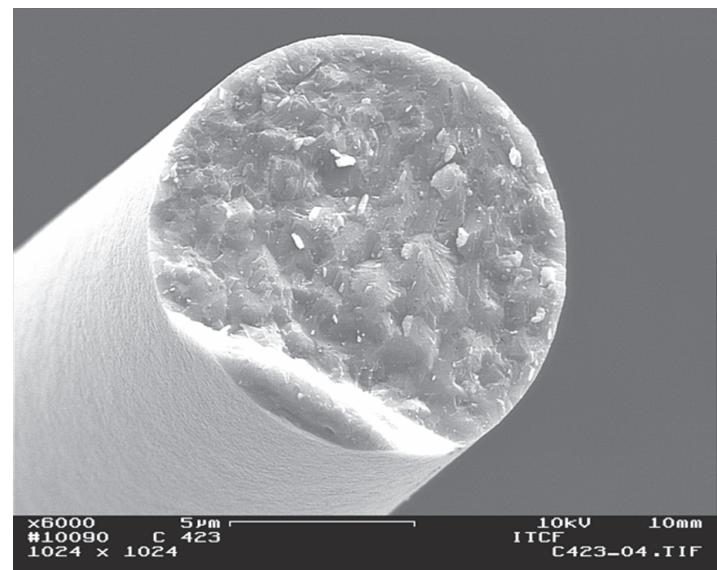

Figure 1.7 Mullite ceramic fibers (produced at ITCF, Denkendorf) as an example for oxide ceramic fibers.

1.5

Carbon Fibers

Carbon belongs to the materials with the highest temperature resistance, if kept in non-oxidizing atmosphere. Under these conditions carbon does not sublimate until temperatures of $3730^{\circ} \mathrm{C}$ are reached. The material can be used in technical applications up to $2800^{\circ} \mathrm{C}$.

Well-known modifications of carbon are diamond, graphite, amorphous carbon, and also fullerenes and carbon nanotubes.

In graphite, each atom is bonded trigonally to three other atoms, making a strong two-dimensional network of flat six-membered rings; the bond energies in between the planes are weak (Figure 1.9, left). 
\begin{tabular}{l|l}
1.5 Carbon Fibers & 13
\end{tabular}

Table 1.4 Overview about commercial non-oxide ceramic filament fibers.

\begin{tabular}{|c|c|c|c|c|c|c|}
\hline Producer Fiber & $\begin{array}{l}\text { Composition } \\
\text { (Wt.-\%) }\end{array}$ & Diameter $(\mu \mathrm{m})$ & $\begin{array}{l}\text { Density } \\
\left(\mathrm{g} / \mathrm{cm}^{3}\right)\end{array}$ & $\begin{array}{l}\text { Tensile } \\
\text { strength/ } \\
\text { modulus } \\
(\mathrm{MPa} / \mathrm{CPa})\end{array}$ & $\begin{array}{l}\text { Production } \\
\text { technique/ } \\
\text { structure }\end{array}$ & $\begin{array}{l}\text { Approx. } \\
\text { price }\end{array}$ \\
\hline $\begin{array}{l}\text { Nippon Carbon } \\
\text { Hi-Nicalon "S" }\end{array}$ & $\begin{array}{l}\text { Si: } 68.9 \\
\text { C: } 30.9 \\
\text { O: } 0.2\end{array}$ & 12 & 3.10 & $2600 / 420$ & $\begin{array}{l}\text { Polycarbosilane/ } \\
\quad \beta-\mathrm{SiC}\end{array}$ & $\begin{array}{l}€ 7000 / \mathrm{kg} \\
>10 \mathrm{~kg}\end{array}$ \\
\hline $\begin{array}{l}\text { Nippon Carbon } \\
\text { Hi-Nicalon }\end{array}$ & $\begin{array}{l}\text { Si: } 63.7 \\
\text { C: } 35.8 \\
\text { O: } 0.5\end{array}$ & 14 & 2.74 & $2800 / 270$ & $\begin{array}{c}\text { Polycarbosilane/ } \\
\beta-\mathrm{SiC}+\mathrm{C}\end{array}$ & $\begin{array}{l}€ 3250 / \mathrm{kg} \\
>10 \mathrm{~kg}\end{array}$ \\
\hline $\begin{array}{l}\text { Nippon Carbon } \\
\text { Nicalon NL-200/201 }\end{array}$ & $\begin{array}{l}\text { Si: } 56.5 \\
\text { C: } 31.2 \\
\text { O: } 12.3\end{array}$ & 14 & 2.55 & $3000 / 220$ & $\begin{array}{l}\text { Polycarbosilane/ } \\
\quad \beta-\mathrm{SiC}+\mathrm{SiO}_{2}+\mathrm{C}\end{array}$ & $\begin{array}{l}€ 1000 / \mathrm{kg} \\
>10 \mathrm{~kg}\end{array}$ \\
\hline $\begin{array}{l}\text { UBE Industries } \\
\text { Tyranno Fiber SA } 3\end{array}$ & $\begin{array}{l}\text { Si: } 67.8 \\
\text { C: } 31.3 \\
\text { O: } 0.3 \\
\text { Al: }<2\end{array}$ & $10 / 7.5$ & 3.10 & $2800 / 380$ & $\begin{array}{r}\text { Polycarbosilane/ } \\
\beta \text {-SiC } \text { cryst. }^{+} \ldots\end{array}$ & $\begin{array}{l}€ 6500 / \mathrm{kg} \\
>10 \mathrm{~kg}\end{array}$ \\
\hline $\begin{array}{l}\text { UBE Industries } \\
\text { Tyranno Fiber ZMI }\end{array}$ & $\begin{array}{l}\text { Si: } 56.1 \\
\text { C: } 34.2 \\
\text { O: } 8.7 \\
\text { Zr: } 1.0\end{array}$ & 11 & 2.48 & $3400 / 200$ & $\begin{array}{c}\text { Polycarbosilane/ } \\
\quad \beta-\mathrm{SiC}+\ldots\end{array}$ & $\begin{array}{l}€ 1400 / \mathrm{kg} \\
>10 \mathrm{~kg}\end{array}$ \\
\hline $\begin{array}{l}\text { UBE Industries } \\
\text { Tyranno Fiber LoxM }\end{array}$ & $\begin{array}{l}\text { Si: } 55.4 \\
\text { C: } 32.4 \\
\text { O: } 10.2 \\
\text { Ti: } 2.0\end{array}$ & 11 & 2.48 & $3300 / 187$ & $\begin{array}{l}\text { Polycarbosilane/ } \\
\quad \beta \text {-SiC }{ }_{\text {amorph. }}+\ldots\end{array}$ & $\begin{array}{l}€ 1200 / \mathrm{kg} \\
>10 \mathrm{~kg}\end{array}$ \\
\hline $\begin{array}{l}\text { UBE Industries } \\
\text { Tyranno Fiber S }\end{array}$ & $\begin{array}{l}\text { Si: } 50.4 \\
\text { C: } 29.7 \\
\text { O: } 17.9 \\
\text { Ti: } 2.0\end{array}$ & $8.5 / 11$ & 2.35 & $3300 / 170$ & $\begin{array}{l}\text { Polycarbosilane/ } \\
\quad \beta-\mathrm{SiC}_{\text {amorph. }}+\ldots\end{array}$ & $\begin{array}{l}€ 1000 / \mathrm{kg} \\
>10 \mathrm{~kg}\end{array}$ \\
\hline $\begin{array}{l}\text { COI Ceramics } \\
\text { Sylramic-iBN }\end{array}$ & $\mathrm{SiC} / \mathrm{BN}$ & 10 & 3.00 & $3000 / 400$ & $\begin{array}{l}\text { Precursor-polymer/ } \\
\text { SiC/BN and } \\
\text { other phases }\end{array}$ & $\begin{array}{l}€ 10500 / \mathrm{kg} \\
>10 \mathrm{~kg}\end{array}$ \\
\hline $\begin{array}{l}\text { COI Ceramics } \\
\text { Sylramic }\end{array}$ & $\begin{array}{l}\mathrm{SiC}: 96.0 \\
\mathrm{TiB}_{2}: 3.0 \\
\mathrm{~B}_{4} \mathrm{C}: 1.0 \\
\mathrm{O}: 0.3\end{array}$ & 10 & 2.95 & $2700 / 310$ & $\begin{array}{l}\text { Precursor-polymer/ } \\
\text { SiC and other } \\
\text { phases }\end{array}$ & $\begin{array}{l}€ 8500 / \mathrm{kg} \\
>10 \mathrm{~kg}\end{array}$ \\
\hline $\begin{array}{l}\text { Specialty Materials } \\
\text { SCS-Ultra }\end{array}$ & $\mathrm{SiC}$ on $\mathrm{C}$ & $\begin{array}{l}140 \text { (with } \\
\text { carbon fiber } \\
\text { core) }\end{array}$ & 3.0 & $5865 / 415$ & $\begin{array}{l}\text { CVD on } \\
\text { C-filament } / \beta-S i C \\
\text { on C }\end{array}$ & $€ 16400 / \mathrm{kg}$ \\
\hline $\begin{array}{l}\text { Specialty Materials } \\
\text { SCS-9A }\end{array}$ & $\mathrm{SiC}$ on $\mathrm{C}$ & $\begin{array}{l}78 \text { (with } \\
\text { carbon fiber } \\
\text { core) }\end{array}$ & 2.8 & $3450 / 307$ & 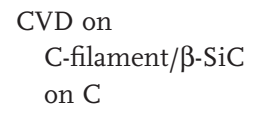 & $€ 19600 / \mathrm{kg}$ \\
\hline $\begin{array}{l}\text { Specialty Materials } \\
\text { SCS-6 }\end{array}$ & $\mathrm{SiC}$ on $\mathrm{C}$ & $\begin{array}{l}140 \text { (with } \\
\text { carbon fiber } \\
\text { core) }\end{array}$ & 3.0 & $3450 / 380$ & $\begin{array}{l}\text { CVD on } \\
\text { C-filament//-SiC } \\
\text { on C }\end{array}$ & $€ 4850 / \mathrm{kg}$ \\
\hline $\begin{array}{l}\text { Tisics } \\
\text { Sigma }\end{array}$ & $\mathrm{SiC}$ on $\mathrm{W}$ & $\begin{array}{l}\text { 100/140 (with } \\
\text { tungsten } \\
\text { wire core) }\end{array}$ & 3.4 & $4000 / 400$ & $\begin{array}{l}\text { CVD on } \\
\text { W-filament/SiC } \\
\text { on W }\end{array}$ & $\begin{array}{l}\text { Price not } \\
\text { available }\end{array}$ \\
\hline
\end{tabular}




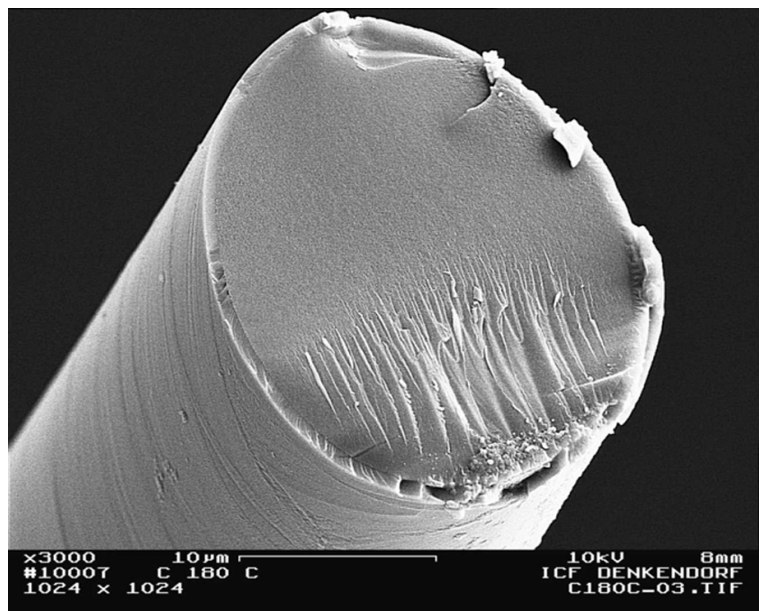

Figure 1.8 Si-C-N-fibers (ITCF, Denkendorf), produced from a polycarbosilazane precursor (University of Bayreuth). The depicted fiber was already treated for $12 \mathrm{~h}$ at $1500^{\circ} \mathrm{C}$ in air [5].
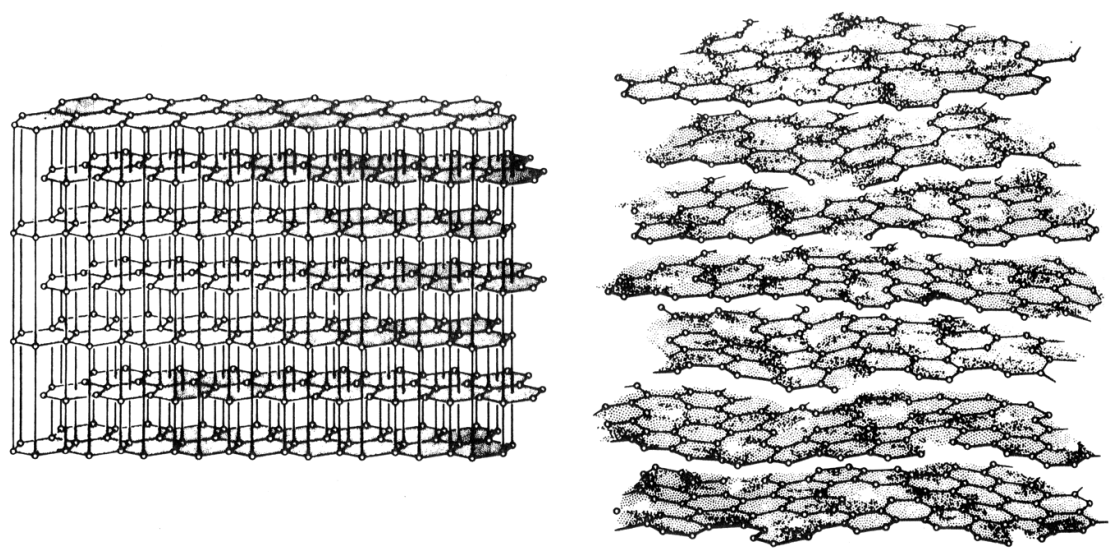

Figure 1.9 Carbon structures. Left: perfect graphite crystal, right: turbostratic structure, which is present in carbon fibers [31].

In carbon fibers, a layered structure is present, but unlike true graphite, the graphitic layers are not neatly stacked, but have a more random arrangement [29, 30]. The layers are also not planar but rather ondulated, so this structure is called "turbostratic" [31] (Figure 1.9 right). It is therefore appropriate to refer to the structure of PAN-based carbon fibers as turbostratic graphite. In fibers derived from mesophase pitch precursors, structures are formed closer to the true graphite structure.

In order to achieve carbon fibers with high tensile strengths and moduli, the carbon planes have to be oriented toward the fiber axis and optimized in their 


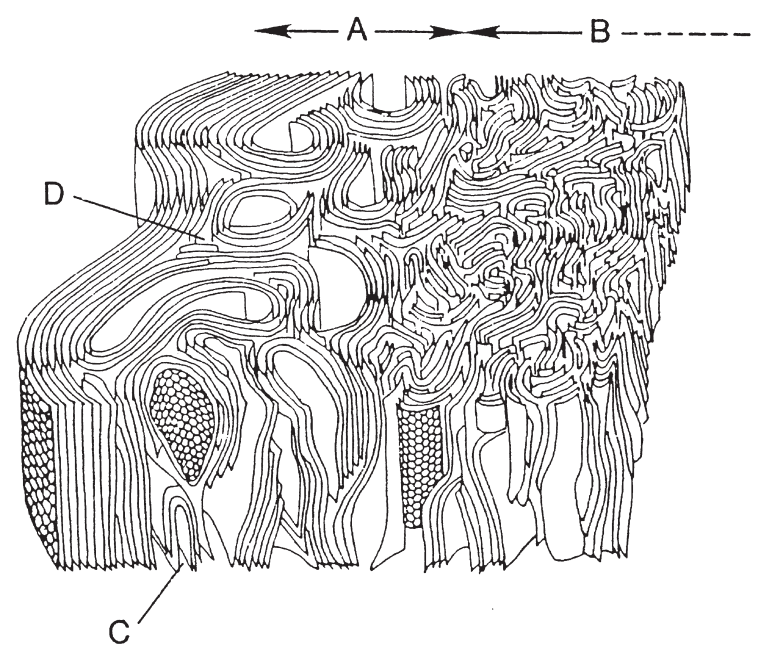

Figure 1.10 Structure of PAN derived carbon fiber with different substructures: $A$ = surface region; $B$ = bulk region; $C=$ "hairpin" defect; $D=$ disclination [32].

structure. This can be done by temperature treatments in an inert atmosphere under tension.

Perpendicular to the fiber axis there is usually no orientation of the carbon planes. This type of structure is present in all carbon fibers, but nevertheless there are differences in terms of degree of orientation, arrangement of the layers in radial direction, interaction in between the planes, and the presence of different structural flaws such as microvoids and other imperfections [32] (Figure 1.10). This leads to fibers with different mechanical properties, from high tensile strength to very high modulus.

The elastic modulus of the fibers depends mainly on the degree of orientation of the planes along the fiber axis, whereas the tensile strength is limited by the number of structural flaws. During temperature treatments up to $1500^{\circ} \mathrm{C}$, the tensile strength tends to be optimized and treatments at even higher temperatures (up to $2800^{\circ} \mathrm{C}$ ) lead to fibers with high moduli.

For the use of carbon fibers in CMCs, such as $\mathrm{C} / \mathrm{SiC}$ (carbon fiber reinforced silicon carbide), the fibers have to be protected against oxidation. Otherwise they will deteriorate by oxidative degradation at temperatures above $450^{\circ} \mathrm{C}$. The fibers can be protected against oxidation by the surrounding matrix itself but in most cases the composite has to be protected additionally by a so-called EBC.

\subsection{1}

\section{Production Processes}

\subsubsection{Carbon Fibers from PAN Precursors}

The starting materials for this process are polyacrylonitrile fibers produced especially for carbon fiber manufacturing. The composition of the PAN is different 


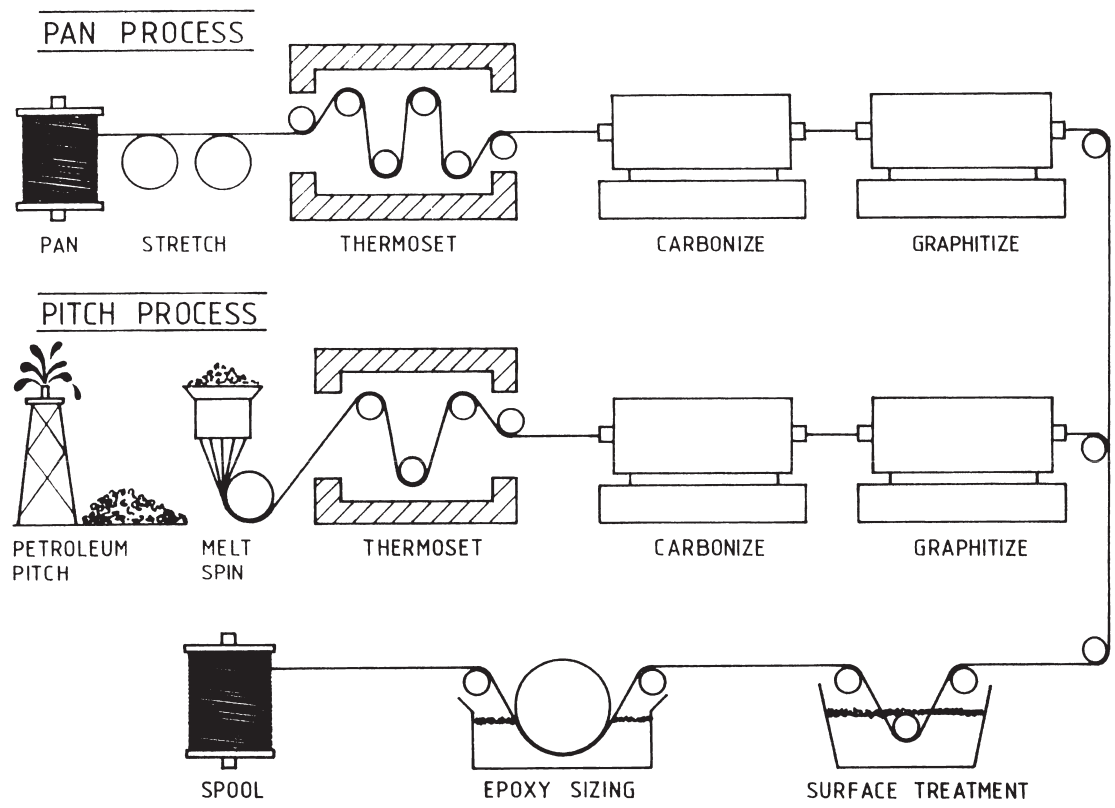

Figure 1.11 Two important production processes for carbon fibers [31].

from the others used for textile applications (different co-monomers are used for the polymerization of acrylonitrile).

The PAN fibers are first treated under tension in a stabilization step in an oxidizing atmosphere at temperatures between 250 and $300^{\circ} \mathrm{C}$. In this process, the linear PAN chain molecules are transformed to a material with cyclic and ladderlike structure elements, which can withstand further treatments at higher temperatures [31] (Figure 1.11, top). In the next step, the fibers are treated at 500 to $1500^{\circ} \mathrm{C}$ in an inert atmosphere (nitrogen), also under tension, which leads to carbonization of the fibers. In this process, non-carbon elements are removed as volatile products, yielding carbon fibers with about $50 \%$ the mass of the original PAN precursor. During this carbonization, the carbon plains are optimized in their structure (reduction of the number of structural flaws), leading to fibers with high tensile strength.

In additional high temperature steps (graphitization) in a nitrogen or argon atmosphere, the fiber structure can be further improved to produce high moduli. Temperatures up to $2800^{\circ} \mathrm{C}$ are applied to arrange the carbon plains and to increase their orientation toward the fiber axis. However, X-ray diffraction patterns show that in this state no true graphitic structure is formed.

Typically fibers, which have been treated only at $1000^{\circ} \mathrm{C}$, exhibit tensile strength values of about $2000 \mathrm{MPa}$ and tensile moduli of about $170 \mathrm{GPa}$.

After temperature treatments up to $1500^{\circ} \mathrm{C}$, tensile strengths of about $3500 \mathrm{MPa}$ and tensile moduli of about $275 \mathrm{GPa}$ are reached. 
At $2500^{\circ} \mathrm{C}$, fibers with reduced tensile strengths of about $2800 \mathrm{MPa}$ are formed (presumably by the evolution of prolate pores during the formation of more compact crystalline structures), but these fibers have very high tensile moduli of $480 \mathrm{GPa}$.

Even higher values for tensile moduli (up to $600 \mathrm{GPa}$ ) can be reached, if the fibers are treated at high temperature under tension.

The PAN process is by far the most important production process for carbon fibers.

\subsubsection{Carbon Fibers from Pitch Precursors}

Pitches derived from coal tar, petroleum residues, or PVC can be used as relatively cheap precursors for carbon fibers.

Pitch is a thermoplastic material and can therefore be extruded directly via melt spinning processes to precursor fibers. These can be subsequently transferred to carbon fibers in processes similar to the one described for the PAN route. This includes a stabilization step between 250 and $300^{\circ} \mathrm{C}$ and then carbonization and graphitization at temperatures between 1000 and $2500^{\circ} \mathrm{C}$ [31] (Figure 1.11, lower).

In untreated pitches, condensed aromatic structures are present, which are isotropic and randomly distributed. This leads to fibers with low orientation of the carbon plains along the fiber axis, and moderate mechanical properties.

In order to achieve enhanced fiber properties, the pitches are thermally treated at 400 to $450^{\circ} \mathrm{C}$ by which liquid crystalline, anisotropic structures are formed, the so-called mesophases.

Precursor fibers, produced from mesophase pitch, exhibit high orientation values of the carbon plains in the direction of the fiber axis and can therefore be transformed to carbon fibers with very good mechanical properties. The yield of carbon from pitches can be above $75 \mathrm{wt} .-\%$.

Tensile strengths values of $3500 \mathrm{MPa}$ and tensile moduli of about $400 \mathrm{GPa}$ can be reached for the carbon fibers based on pitch. Also, this fiber type can be brought to even higher moduli of about $600 \mathrm{GPa}$ by an additional high temperature treatment.

\subsubsection{Carbon Fibers from Regenerated Cellulose}

For this production route, cellulose rayon fibers are used as a carbon source. Rayon fibers are produced by dissolving and spinning of cellulosic materials, such as wood pulp or cotton.

Since cellulose is a polymeric carbohydrate, water evolves during the temperature treatment, leaving a residue of carbon.

The production process is also conducted in steps, including a lower temperature treatment (below $400^{\circ} \mathrm{C}$ ), subsequent carbonization (up to $1500^{\circ} \mathrm{C}$ ), and graphitization (at about $2500^{\circ} \mathrm{C}$ ). The yield of carbon fibers from rayon is low, ranging between 10 and $30 \mathrm{wt} . \%$.

The mechanical properties of the rayon derived carbon fibers achieved in standard processing (only carbonization) are not as good as for PAN derived fibers. 
Typically values of $700 \mathrm{MPa}$ are achieved for the tensile strength and $70 \mathrm{GPa}$ for the modulus.

Unlike in the PAN process, the fibers cannot be held under higher tension during the low temperature treatment. But in the following high temperature treatments, tension can be applied to these fibers, by which good mechanical properties can be reached, that is, tensile strengths up to $2800 \mathrm{MPa}$ and moduli up to $550 \mathrm{GPa}$. Since the whole process is more complex for the rayon derived fibers, PAN derived types are more commonly used in industry.

\section{5 .2}

\section{Commercial Products}

There are a number of companies producing carbon fibers and each has a number of carbon fiber products with different fiber properties and yarn counts. Therefore, no complete market survey of carbon fiber products is given here, but some examples of fiber properties and prices are displayed.

A classification of carbon fibers in terms of their mechanical properties can be conducted by using the IUPAC (International Union of Pure and Applied Chemistry) guidelines (Table 1.5) [33].

Carbon fibers are offered in a wide range of tensile strengths and moduli. Also a wide range of filament numbers in rovings are produced ranging from 1000 (1 K) to 400000 ( $400 \mathrm{~K})$ filament bundles. Depending on the fiber properties, the fibers can be priced between $20 € / \mathrm{kg}$ up to $1500 € / \mathrm{kg}$.

Table 1.6 shows a survey of carbon fibers from Toray, Toho Tenax, and SGL Carbon [34-36].

Some fiber types are sold in different qualities, that is, a regular type and also a type that is qualified for aerospace applications. Since there are higher quality standards in aerospace applications, the fibers for these applications are 15 to $25 \%$ more expensive than those displayed in the table, due to additional quality controls during and after production.

Table 1.5 Classification of carbon fibers.

\begin{tabular}{llll}
\hline Classification & $\begin{array}{l}\text { Tensile } \\
\text { modulus (GPa) }\end{array}$ & $\begin{array}{l}\text { Tensile } \\
\text { strength (MPa) }\end{array}$ & $\begin{array}{l}\text { Elongation } \\
\text { at break (\%) }\end{array}$ \\
\hline UHM (ultra high modulus) & $>600$ & - & - \\
HM (high modulus) & $>300$ & - & $<1$ \\
IM (intermediate modulus) & $275-350$ & - & $>1$ \\
LM (low modulus) & $<100$ & low & - \\
HT (high tensile) & $200-300$ & $>3000$ & $1.5-2$ \\
\hline
\end{tabular}


Table 1.6 Comparison of carbon fibers from different producers.

\begin{tabular}{|c|c|c|c|c|}
\hline Producer Fiber & Diameter $(\mu \mathrm{m})$ & $\begin{array}{l}\text { Density } \\
\left(\mathrm{g} / \mathrm{cm}^{3}\right)\end{array}$ & $\begin{array}{l}\text { Tensile } \\
\text { strength/ } \\
\text { modulus } \\
(\mathrm{MPa} / \mathrm{GPa})\end{array}$ & Approx. price \\
\hline $\begin{array}{l}\text { Toray Industries } \\
\text { T300 (6K) }\end{array}$ & 7 & 1.76 & $3530 / 230$ & $€ 53 / \mathrm{kg}$ \\
\hline $\begin{array}{l}\text { Toray Industries } \\
\text { T700 S (12K) }\end{array}$ & 7 & 1.80 & $4900 / 230$ & $€ 30 / \mathrm{kg}$ \\
\hline $\begin{array}{l}\text { Toray Industries } \\
\text { T800HB (6K) }\end{array}$ & 5 & 1.81 & $5490 / 294$ & $€ 250 / \mathrm{kg}$ \\
\hline $\begin{array}{l}\text { Toray Industries } \\
\text { T } 1000 G(6 K)\end{array}$ & 5 & 1.80 & $7060 / 294$ & $€ 240 / \mathrm{kg}$ \\
\hline $\begin{array}{l}\text { Toray Industries } \\
\text { M60J (6K) }\end{array}$ & 5 & 1.94 & $3920 / 588$ & $€ 1500 / \mathrm{kg}$ \\
\hline $\begin{array}{l}\text { Toho Tenax } \\
\text { HTA } 5131 \text { (3K) }\end{array}$ & 7 & 1.77 & $3950 / 238$ & $€ 59 / \mathrm{kg}$ \\
\hline $\begin{array}{l}\text { Toho Tenax } \\
\text { HTS } 5631 \text { (12K) }\end{array}$ & 7 & 1.77 & $4300 / 238$ & $€ 29 / \mathrm{kg}$ \\
\hline $\begin{array}{l}\text { Toho Tenax } \\
\text { STS } 5631 \text { (24K) }\end{array}$ & 7 & 1.79 & $4000 / 240$ & $€ 22 / \mathrm{kg}$ \\
\hline $\begin{array}{l}\text { Toho Tenax } \\
\text { UMS } 2731 \text { (24K) }\end{array}$ & 4.8 & 1.78 & $4560 / 395$ & $€ 95 / \mathrm{kg}$ \\
\hline $\begin{array}{l}\text { Toho Tenax } \\
\text { UMS } 3536(12 K)\end{array}$ & 4.7 & 1.81 & $4500 / 435$ & $€ 158 / \mathrm{kg}$ \\
\hline $\begin{array}{l}\text { SGL Carbon } \\
\text { Sigrafil } C(50 K)\end{array}$ & 7 & 1.80 & $3800-4000 / 230$ & $€ 15-25 / \mathrm{kg}$ \\
\hline
\end{tabular}

\section{Acknowledgments}

The support of the companies 3M, Sumitomo Chemical, Mitsui, Nitivy, Nippon Carbon, UBE Industries, COI Ceramics, Specialty Materials, Tisics, Toray Industries, Toho Tenax, and SGL Carbon in terms of providing prices and data of ceramic and carbon fibers is gratefully acknowledged.

\section{References}

1 Krenkel, W., Naslain, R. and Schneider, H. (2001) High Temperature Ceramic Matrix Composites, Wiley-VCH Verlag $\mathrm{GmbH}$, Weinheim.

2 Lee, S.M. (1993) Handbook of Composite Reinforcements, Wiley-VCH Verlag $\mathrm{GmbH}$, Weinheim.

3 Clauß, B. (2000) Keramikfasern Entwicklungsstand und Ausblick, Technische Textilien, 43, 246-51.
4 Clauß, B. (2001) Fasern und Performtechniken zur Herstellung Keramischer Verbundstoffe, Keramische Zeitschrift, 53, 916-23.

5 Clauß, B. and Schawaller, D. (2006) Modern Aspects of Ceramic Fiber Development, Advances in Science and Technology, 50, 1-8.

6 Blumberg, H. (1984) Die Zukunft der neuen Hochleistungsfasern, 
Chemiefasern/Textilindustrie, 34/86 $808 \mathrm{ff}$.

7 www.zircarzirconia.com (accessed Oct 08, 2007).

8 Belitskus, D. (1993) Fiber and Whisker Reinforced Ceramics for Structural Applications, Dekker, New York.

9 Bunsell, A.R. (1988) Fibre Reinforcements for Composite Materials, Elsevier Science Publishers B.V., Amsterdam.

10 Ullmann's Encyclopedia of Industrial Chemistry: Fibers; 5: Synthetic Inorganic, Vol. A11 (1988) Wiley-VCH Verlag $\mathrm{GmbH}$, Weinheim, pp. 2-37.

11 Engineered Materials Handbook: Composites, Ceramic Fibers, Vol. 1 (1987) ASM International, Metals Park, Ohio, pp. 60-5.

12 Cooke, Th.F. (1991) Inorganic fibers: A Literature Review, Journal of the American Ceramic Society, 74, 2959-78.

13 Wedell, J.K. (1990) Continuous Ceramic Fibres, Journal of the Textile Institute, 81, 333-59.

14 Bunsell, A.R. (1991) Ceramic Fibers: Properties, Structures and Temperature Limitations, Journal of Applied Polymer Science, Symposium, 47, 87-98.

15 Wallenberger, F.T. (2000) Advanced Inorganic Fibers: Processes, Structures, Properties, Applications, Kluwer Academic Publishers, Dordrecht.

16 Bunsell, A.R. and Berger, M.-H. (1999) Fine Ceramic Fibers, Dekker, New York.

17 http://www.mmm.com/ceramics/misc/ tech_notebook.html (accessed Oct 08, 2007).

18 http://www.sumitomo-chem.co.jp/ english/division/kiso.html (accessed Oct 08, 2007).

19 http://www.nitivy.co.jp/english/nitivy. html (accessed Oct 08, 2007).

20 http://www.mitsui-mmc.co.jp/eindex. html (accessed Oct 08, 2007).

21 Schmücker, M., Schneider, H., Mauer, T. and Clauß, B. (2005)
Kinetics of Mullite Grain Growth in Alumo Silicate Fibers, Journal of the American Ceramic Society, 88, 488-90.

22 Schmücker, M., Schneider, H., Mauer, T. and Clauß, B. (2005) Temperaturedependent evolution of grain growth in mullite fibres, Journal of the European Ceramic Society, 25, 3249-56.

23 www.coiceramics.com (accessed Oct 08, 2007).

24 www.ube.de (accessed Oct 08, 2007).

25 http://www.specmaterials.com/silicarbsite. htm (accessed Oct 08, 2007).

26 http://www.tisics.co.uk/fibre.htm (accessed Oct 08, 2007).

27 Schawaller, D. (2001) Untersuchungen zur Herstellung keramischer Fasern im System Si-B-C-N und Si-C-N, PhD Thesis, University of Stuttgart.

28 Schawaller, D. and Clauß, B. (2001) Preparation of Non-oxide Ceramic Fibers in the Systems Si-C-N and Si-B-C-N, in High Temperature Ceramic Matrix Composites (eds W. Krenkel, R. Naslain and $\mathrm{H}$. Schneider), Wiley-VCH Verlag GmbH, Weinheim, pp. 56-61.

29 Dresselhaus, M.S., Dresselhaus, G., Sugihara, K., Spain, I.L. and Goldberg, H. A. (1988) Graphite Fibers and Filaments, Springer, Berlin.

30 Donnet, J.-B. and Bansal, R.C. (1984) Carbon Fibers, Dekker, New York.

31 Buckley, J.D. (1988) Carbon-carbon; An overview, Ceramic Bulletin, 67, 364-8.

32 Bennett, S.C. and Johnson, D.J. (1978) London International Conference on Carbon and Graphite, Society of Chemical Industry, London.

33 http://goldbook.iupac.org/C00831.html (accessed Oct 08, 2007.

34 http://www.torayca.com/index2.html (accessed Oct 08, 2007).

35 http://www.tohotenax.com/tenax/en/ products/standard.php (accessed Oct 08 2007).

36 http://www.sglcarbon.com/sgl_t/fibers/ sigra_c.html (accessed Oct 08, 2007). 